\section{CHEMISTRY OF BLEOMYCIN. VII}

SYNTHESIS OF $\beta$-AMINO- $\beta$-(4-AMINO6-CARBOXY-5-METHYLPYRIMIDIN2-YL)-PROPIONIC ACID, AN AMINE COMPONENT OF BLEOMYCIN

Sir :

The bleomycins comprise a group of related glycopeptide antitumor antibiotics. By total acid hydrolysis, bleomycin gave at least 6 amino acids and an amine which is specific for each bleomycin ${ }^{1,2)}$. To one of the amino acids, designated compound II in the former report ${ }^{1)}$, we assigned the structure $\beta$-amino$\beta$-(4-amino-6-carboxy-5-methylpyrimidin-2yl)-propionic $\operatorname{acid}^{3)}$ (1). Compound II is<smiles>Cc1c(N)nc(C(N)CC(=O)O)nc1C(=O)O</smiles>

Compound $\|(1)$

(1)<smiles>Cc1c(N)nc(CC(=O)O)nc1C(=O)O</smiles>

(2) in $90 \%$ yield, m. p. $193^{\circ} \mathrm{C}$; NMR in DMSO (internal TMS reference): $\delta 2.09(3 \mathrm{H}$, singlet), 2.87, 3.30 and 4.72 (ABX-pattern, $\mathrm{J}_{\mathrm{AB}}$ $=14.5, \mathrm{~J}_{A X}=9, \mathrm{~J}_{B X}=3 \mathrm{~Hz}$ ). It is obvious that the more reactive 2 -methyl group was involved in this reaction ${ }^{5,6}$. Treatment of 4 with acetic anhydride and pyridine at room temperature yielded almost quantitatively the dehydration product (5), m.p. $177^{\circ} \mathrm{C}$; NMR in DMSO : $\delta 2.16(3 \mathrm{H}$, singlet $)$, 6.89 and 7.67 (trans-olefin, $\mathrm{J}=15 \mathrm{~Hz}$ ). Compound 5 was converted to the corresponding $\alpha, \beta$-unsaturated acid (6) with $95 \% \mathrm{H}_{2} \mathrm{SO}_{4}$ at $70^{\circ} \mathrm{C}$ for 18 hours (94\% yield), NMR in $\mathrm{CD}_{3} \mathrm{OD}: \delta 2.25(3 \mathrm{H}$, singlet), 7.08 and 7.32 (trans-olefin, $J=15 \mathrm{~Hz}$ ). Esterification of 6 with ethanol saturated with hydrogen chloride yielded the di-ethyl ester (gummy, $86 \%$ yield) which was refluxed in $\mathrm{POCl}_{3}$ for 30 minutes to yield 7 (gummy, $70 \%$ yield). Compound 7 gave a spot of Rf 0.80 on silica gel thin-layer chromatography with ethyl acetate and methanol (1:1), while the starting di-ester had Rf 0.62 . Compound 7 was reacted with liquid ammonia in ethanol solution at $135^{\circ} \mathrm{C}$ for 18 hours. The product was without purification, hydrolyzed with $6 \mathrm{~N} \mathrm{HCl}$ at $105^{\circ} \mathrm{C}$ for 18 hours. The final

present as a part of a more complex fragment, termed pseudodipeptide ${ }^{4)}$ (2), in the bleomycin molecule. The pseudodipeptide was obtained by successive selective cleavages of bleomycin ${ }^{4}$. In the process of total acid hydrolysis, the pseudodipeptide moiety gave two amino acids, compound II and $\beta$-aminoalanine, by competitive $\beta$-elimination. In this communication, synthesis of compound II is described.

Compound II has now been obtained from 4-carboxy-2,5dimethyl-6-hydroxypyrimidine ${ }^{3}$ (3) via the following route.

4-Carboxy-2,5-dimethyl-6hydroxypyrimidine (3) (m.p. $242^{\circ} \mathrm{C}$ ) and chloral were reacted at $95^{\circ} \mathrm{C}$ for 44 hours in pyridine. The product (4) was obtained<smiles>Cc1nc(O)c(C)c(C(=O)OC(C)C(=O)O)n1</smiles><smiles>CCOC(=O)c1nc(C=CC2C#C2)nc(Cl)c1C</smiles>

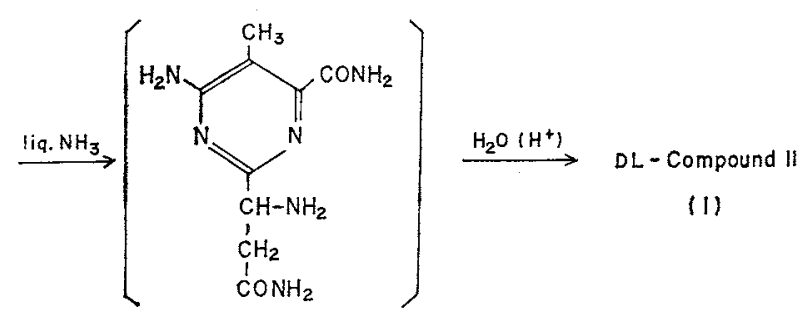


product, compound II (1) was purified with sulfonic acid resin (Dowex 50) column chromatography (20\% yield).

The behavior on thin-layer chromatography, paper electrophoresis and UV and NMR spectra were the same as natural II. The IR spectrum was different from natural II, because natural II is partially racemized while the synthetic material is completely racemic.

Since the pseudodipeptide has been derived from compound II and methyl acetamidoacrylate $^{4)}$, the total synthesis of pseudodipeptide has been accomplished.

\section{Takeo Yoshioka Yasuhiko Muraoka* Tomohisa Takita** KenJi MaEda Hamao Umezawa}

Institute of Microbial Chemistry, 3-14-23, Kamiosaki, Shinagawa-ku, Tokyo, Japan 141

* Research Laboratory, Pharmaceutical Division Nippon Kayaku Co., Ltd., 3-31-12, Shimo, Kita-ku, Tokyo, Japan 115

** Author to whom correspondence should be addressed.

(Received August 7, 1972)

\section{References}

1) TAKIta, T.; Y. MUraOKa, K. MAEDA \& H. UMEZAWA : Chemical studies on bleomycins. I. The acid hydrolysis products of bleomycin $A_{2}$. J. Antibiotics $21: 79 \sim 80,1968$

2) TAKITA, T.; Y. MURAOKA, S. OMOTO, G. Koyama, A. FUJII, K. MAEDA \& H. UMEZAWA: Chemical studies on an antitumor antibiotic, bleomycin $\mathrm{A}_{2}$. Proc. 6 th Internat. Congr. Chemoth., Progress in Antimicrobial and Anticancer Chemotherapy. Vol. II, pp. 1031 1036, 1969

3) MURAOKA, Y.; T. TAKITA, K. MAEDA \& H. UMEZAWA : Chemistry of bleomycin. IV. The structure of amine component II of bleomycin $A_{2}$. J. Antibiotics $23: 252 \sim 253,1971$

4) TAKITA, T.; Y. Muraoka, K. Maeda \& H. UMEZAWA: Selective cleavage of bleomycin. Proc. 8 th Symp. on Peptide Chem. Osaka, pp. 179 183, 1970

5) Jones, R.G.; E. KORNFELd \& K. McLaUGhLiN : The synthesis of some $\beta$-aminoethyldiazines as histamine analogs. J. Am. Chem. Soc. $72: 3539 \sim 3542,1950$

6) Brown, D. J.: The Pyrimidines. pp. 124 128. Interscience Publishers, New York, 1962 